\title{
DETECTION OF VERTICAL DEFORMATION IN JAKARTA-BANDUNG HIGH SPEED TRAIN ROUTE USING X SAR AND SENTINEL
}

\author{
Atriyon JULZARIKA ${ }^{1,2^{*}}$, Catur Aries ROKHMANA ${ }^{2}$ \\ ${ }^{1}$ Remote Sensing Applications Center, Indonesian National Institute of Aeronautics and Space (LAPAN), \\ Jakarta, Indonesia \\ ${ }^{2}$ Geodesy Geomatics Engineering, Universitas Gadjah Mada (UGM), Yogyakarta, Indonesia
}

Received 10 July 2019; accepted 22 November 2019

\begin{abstract}
The Jakarta-Bandung high speed train is one of the national strategic plans. The high speed train route connects the Jakarta city to the Bandung city. The route needs to be detailed topography and checking of vertical deformations that occur along its route. This study aims to determine the conditions of vertical deformation in four stations and the Jakarta Bandung high speed train route. The spatial information of vertical deformation was extracted from the X SAR (2000) and Sentinel data (2018). The method used was Differential Interferometry Synthetic Aperture Radar (DinSAR). The vertical deformation was obtained from the reduction of topography in 2018 with the topography of 2000. Both of these topography must meet the tolerance of 1.96 sigma so that the resulting deformation is also more optimal. The results of this study can be used to reference the determination of high speed train route based on conditions of vertical deformation.
\end{abstract}

Keywords: vertical deformation, DinSAR, High speed train, X SAR, Sentinel.

\section{Introduction}

The first high-speed train project in Indonesia has been planned and will connect the Jakarta city with the Bandung city with a distance of $150 \mathrm{~km}$ (Wikipedia, 2018). Plans for the construction of high-speed trains in Indonesia were announced by the government in July 2015. The project is also expected to develop further by connecting the city of Jakarta with the city of Surabaya. Japan and the People's Republic of China have expressed their interest in participating in this project tender. Previously, the two Asian countries had held a comprehensive study of this project (Wikipedia, 2018). High speed trains have been made in developed countries such as the Netherlands (Esveld, 2001), China (Chang, Dollevoet, \& Hanssen, 2014) and several developing countries. The Jakarta-Bandung high speed train route is located in the regional geology of West Java. This region has unique geological conditions with certain characteristics. This geological condition includes the physiography and regional stratigraphy of West Java. According to Bemmelen (1949), West Java physiography has 4 zones with geological characteristics consisting of alluvial plains, folded hills, and volcanoes. The 4 zones are the Jakarta zone, Bogor zone, Bandung zone, and the southern mountain zone. This study aims to map vertical deformations from 2000-2018 in the area of the Jakarta-Bandung high speed train route plan.

\section{Study area}

This high speed train route covers the Jakarta, Bogor, and Bandung zones. The Jakarta zone is on the north coast of Java with a width of about $40 \mathrm{~km}$. This area stretches from Serang to Cirebon. Some of this area is covered by transported alluvial deposits. The Bogor zone stretches from Rangkasbitung, Bogor, Purwakarta, Subang, Sumedang, Kuningan, and Majalengka. This area is a folded hill formed from tertiary marine sedimentary rocks forming an anticlonorium, in some places experiencing faults estimated in the Pliocene-Plistocene period of time with the formation of Lembang faults and the removal of the Southern Mountains. At present the Bogor zone consists of low hills and places where there are vulcanic necks. In addition there are also intrusive rocks in Mount Parang and Mount Sanggabuana on Plered Purwakarta, Mount Kromong and Mount Buligir in Majalengka. Mount Ciremai, Kuningan and Mount Tampomas, Sumedang are boundaries of the Bogor zone with the Bandung zone.

*Corresponding author. E-mail: verbhakov@yahoo.com 
The Bandung zone is a volcanic area. This zone is a depression zone and has the potential for deformation, both vertical and horizontal. This zone has a crease estimated since the Tertiary era. The Bandung zone is mostly filled with young volcanic deposits. Volcanoes in this zone are located in the lowlands between the Bogor zone and the southern mountain zone. Some of the Bandung zones are filled with alluvial and young vulcanic deposits, but in some places they are a mixture of tertiary and quaternary deposits.

Based on the regional stratigraphy of West Java, this high speed train area has a stratigraphy which is a melange complex, namely a zone of mixing between oceanic crustal rocks and continental crustal rocks. In this zone consists of metamorphic, volcanic and igneous rocks, which are known only from drilling data in the northern part of the West Java sea (Martodjojo, 1984).

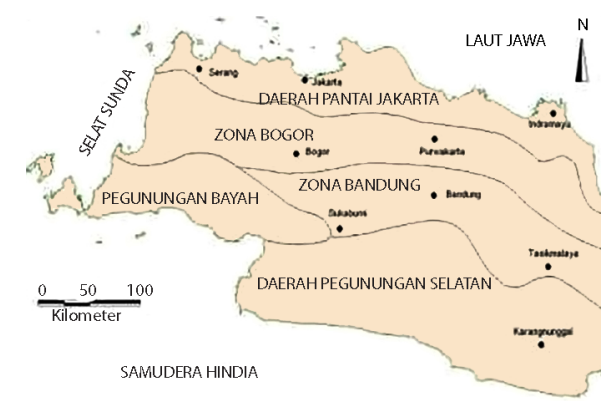

Figure 1. Physiograpgy of West Java (Bemmelen, 1949)

In the early tertiary (peleocene) melange complex was formed in the southwest of West Java (Cileutuh Bay) which was thought to be part of the subduction zone in the direction of Central Java. The northern region of West Java is known as the Jatibarang formation. This region is a product deposition resulting from volcanic eruptions. In the Eocene era, West Java was on continental conditions. This is indicated by the geological inconsistency of its formation. Rajamandala-Sukabumi is the terrestrial fluvial area. This area is a Gunung Walat formation that fills the interarc basin depression (Bemmelen, 1949).

\section{Data and methodology}

\subsection{Remote Sensing}

Remote Sensing is the science, art and technique for obtaining information on an object, area, and/or phenomenon through analysis of data obtained by a tool without having to contact directly with objects, regions, or phenomena studied (Lillesand \& Kiefer, 1994; Bates \& Jackson, 1987). Indonesia is prone to geological disasters because it is located at tectonic plates. Geological disasters that frequently hit Indonesia include earthquakes, volcanic eruptions, land movements, and tsunamis. This geological disaster is generally caused by geodynamics in the form of vertical deformation and horizontal deformation. Information and knowledge about geological disasters is needed for disaster mitigation (Monserrat, Crosetto, \& Luzi, 2014). One way to get this information is using remote sensing data.

In principle, every object and natural phenomenon in the surface of the earth can be detected from satellite imagery. The ability of satellite imagery to detect objects and natural phenomena that occur depends on the resolution, both spatial, spectral, radiometric, and temporal. Geological disasters are generally related to geological processes, namely processes that originate from the surface of the earth (exogenous) or beneath the surface of the earth (endogenous) which involves its constituent rock material. With the help of remote sensing imagery, mapping can be made in the form of factors that can affect the occurrence of disasters and management in the face of disasters in an area. This is very important in the management of an area prone to disasters, so as to reduce the impact of the disaster.

\subsection{Deformation}

Deformation is a change in the shape, position, and dimensions of an object (Kuang, 1996). Deformation can be interpreted as a change in the position or movement of a point in an object in absolute or relative terms. Absolute deformation occurs if the behavior of the movement is at the point itself. Relative deformation occurs if the movement is assessed from another point (Luzi, Del Ventisette, \& Casagli, 2010). Change in position or movement of a point generally refers to a particular system and reference field (absolute or relative) (Berardino, Fornaro, Lanari, \& Sansosti, 2002).

Deformation can be known in two ways, namely deformation and geodynamics surveys (Crosetto et al., 2005). Deformation and geodynamics surveys themselves are geodetic surveys conducted to study the phenomenon of deformation and geodynamics. This phenomenon is a natural phenomenon and other phenomena (Chang, Dollevoet, \& Hanssen, 2017). Natural phenomena such as plate tectonic movements, volcanic activities, and others. Other phenomena are human phenomena such as buildings, bridges, dams, land surfaces, and so on. Deformation analysis can be done geometrically (Chrzanowski, 1986). This geometric analysis is a shift and strain.

\subsection{Interferometric Synthetic Aperture Radar}

Interferometric Synthetic Aperture Radar (InSAR) is remote sensing technology that uses radar images sensor from air/satellite aircraft (Julzarika \& Susanto, 2009; Monserrat, 2012) or a technique used to extract three-dimensional (3D) information from the surface of the earth by observing the radar wave phase (Julzarika \& Susanto, 2009; (Nico, Leva, Fortuny-Guasch, Antonello, \& Tarchi, 2005). Radar sensors on airplanes and satellites emit radar waves constantly, then the radar waves are recorded after being received back by the sensor due to being reflected by targets on the earth's surface (Reale, Serafino, \& Pascazio, 2009). 
Initially radar interferometry was used for observing the surface of the moon and planet Venus. In 1974, this technique was first applied in the field of mapping. To obtain the topography of the image must be fulfilled two conditions, namely objects on the surface of the earth that are imaged must be clearly visible or have high image resolution so that interpretation and identification can be carried out accordingly (Hanssen, 2001). Radar images obtained from aircraft or satellites contain two important information. This information is the emission power in the form of phase and amplitude which is influenced by the number of waves emitted and reflected back (Ferretti et al., 2011).

Radar images are obtained from aircraft and/or satellites (Liu et al., 2011). This image contains information about the emission power in the form of amplitude and phase which is influenced by the number of waves emitted and reflected back (Fifamè Koudogbo et al., 2018). When the wave is emitted, phase measurements are made. Signal intensity can be used to determine the characteristics of objects that reflect the wave (Ferretti, Prati, \& Rocca, 2001). The wave phase is used to determine the distance from the satellite to the object (Hyangsun \& Hoonyol, 2011). The distance analysis can be used for the extraction of height models in the form of Digital Surface Model (DSM) and high changes in vertical deformation (Jungner, 2009; Rödelsperger et al., 2010).

InSAR uses differences in phase measurements to get distance differences and distance changes from two or more SAR images that have complex values from the same surface (Pieraccini et al., 2004). The result of the difference from this phase produces a new type of image (Ulaby, Moore, \& Fung, 1986). The difference is called interferogram (Cuenca, Hooper, \& Hanssen, 2013). These interferograms have a color circle pattern (fringes) in the surface shape of the topography (Crosetto, Monserrat, Cuevas, \& Crippa, 2011).

\subsection{SAR}

The mission of Topography Shuttle Radar (SRTM, DTS99) from 11 to 22 February 2000 is a US-German-Italian effort to produce the first global Digital Elevation Model (DEM) (DLR, 2019). The German Aerospace Center (DLR) and the Italian Space Agency (ASI) complete NASA/JPL C-band Synthetic Aperture Radar (SAR) loads with additional X-SAR instruments. SRTM X-SAR DEM is generated on the DLR from this instrument data using radar interferometry techniques. Data was obtained simultaneously from the space shuttle Endeavor using two SAR antennas, one inside the Space Shuttle cargo space, the other at the end of the $60 \mathrm{~m}$ extension pole.

Most of the global land surface between $60^{\circ}$ North Latitude and $58^{\circ}$ South Latitude is covered. Because the orbit flown and the imaging period of the SRTM mission have been optimized for United States C-band systems, the German-Italian X-SAR with a narrower aperture angle images the data for only about $50 \mathrm{~km}$ of the orbital ground trace approximately. Therefore, the available dataset shows grid-like coverage. The original SRTM DTED SRED XSAR DEM has been merged into tile $10 \times 10^{\circ}$, converted to GeoTIFF format and packaged in a zip archive (DLR, 2019). Each zip file contains a DEM dataset, suitable altitude error map (HEM), quicklook in *.png image display, ${ }^{*} . \mathrm{kml}$ overlay and readme document. The zip-file archive name specifies the lower left coordinates of each tile. Zipped archives can be downloaded via EOC Download Services (DLR, 2019).

\subsection{Sentinel 1}

European Space Agency [ESA] is developing a new mission family called Sentinel specifically for the operational needs of the Copernicus program (ESA, 2019). Each Sentinel mission is based on a constellation of two satellites to meet the review and coverage requirements, providing a strong data set for the Copernicus program. These missions carry a variety of technologies, such as radar and multi-spectral imaging instruments for terrestrial, marine and atmospheric monitoring (ESA, 2019).

The mission of the Copernicus program includes 5 satellites namely Sentinel-1, Sentinel-2, Sentinel-3, Sentinel 5-Precursor, Sentinel-4, Sentinel-5, and Sentinel-6. Sentinel-1 is an orbiting radar imaging mission, all weather, day and night for land and sea services. Sentinel-1A was launched on April 3, 2014 and Sentinel-1B on April 25, 2016. Both were taken into orbit using Soyuz rockets from the European Spaceport in French Guiana. The Sentinel-1 mission comprises a constellation of two polar-orbiting satellites, operating day and night performing C-band synthetic aperture radar imaging, enabling them to acquire imagery regardless of the weather (ESA, 2019).

\subsection{Research methodology}

This study follows the research flowchart attached in Figure 2. The flowchart of this study uses radar data. The research flowchart can be seen in Figure 2. Location of

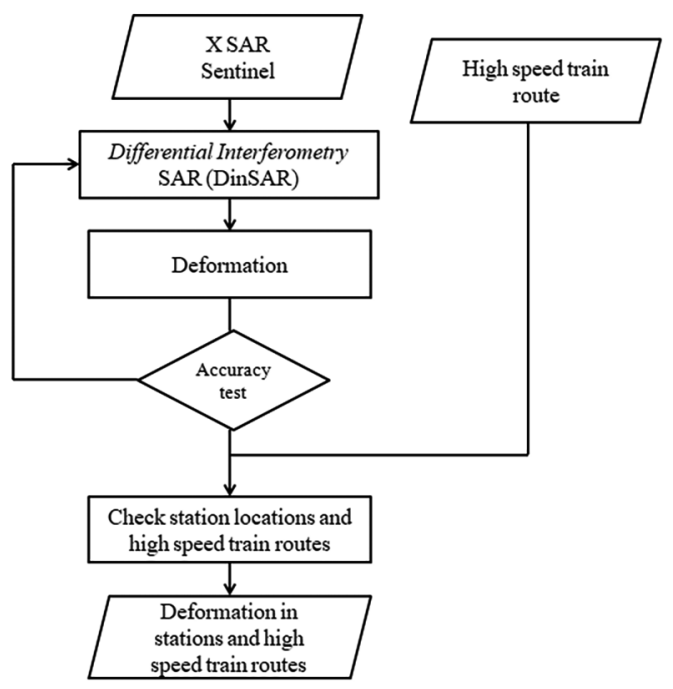

Figure 2. Research flowchart 
this research is in Jakarta-Bandung high speed train route. Data in this research are X SAR in 2000, Sentinel in 2018, and Jakarta-Bandung high speed train route vector.

$\mathrm{X}$ SAR and Sentinel are made topographically by interferometry. After that deformation was carried out using the Differential Interferometry Synthetic Aperture Radar (DinSAR) method (Ferretti, Prati, \& Rocca, 2000; Robles, Gomar, \& Arnaud, 2015). In simple terms, DinSAR is a reduction of two topographies at a minimum of 2 time periods (Chang \& Hanssen, 2016). If you use a lot of data for deformation calculations you can use the method of Persistent Scatterer Interferometry (PS InSAR) (van Leijen, 2014).

In this study the time period carried out by checking vertical deformation was 2000 and 2018 using DinSAR method. This deformation needs to be tested for the its accuracy (Luo, Perissin, Lin, Zhang, \& Wang, 2014). If the topography has met the tolerance of $1.96 \sigma$ with an accuracy test then the deformation also meets tolerance. Then the train track data is quickly overlaid at the deformation. This aims to determine the deformations that occur along the Jakarta-Bandung high speed train route and the deformations that occur at these 4 high speed train stations. The final results obtained in this research are spatial information about deformations that occurred in the period 2000-2018 along the high speed train route and 4 high speed train stations.

\section{Results and discussion}

\subsection{Vertical deformation}

Vertical deformation is detected using X SAR and Sentinel data. Vertical deformation monitored is 2000-2018. The X SAR data used is in 2000. The Sentinel data used is 2018.

a)

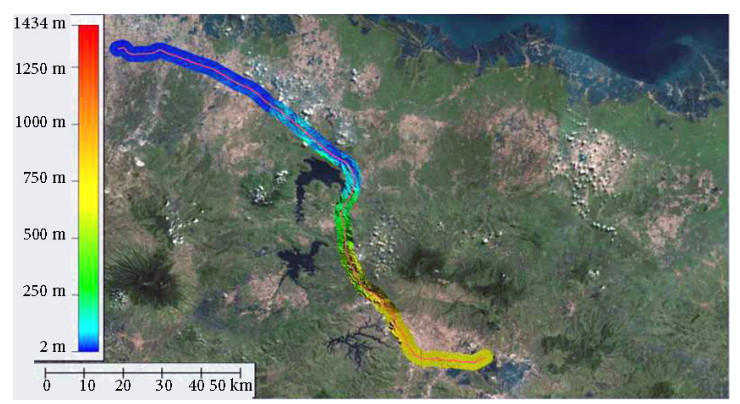

b)

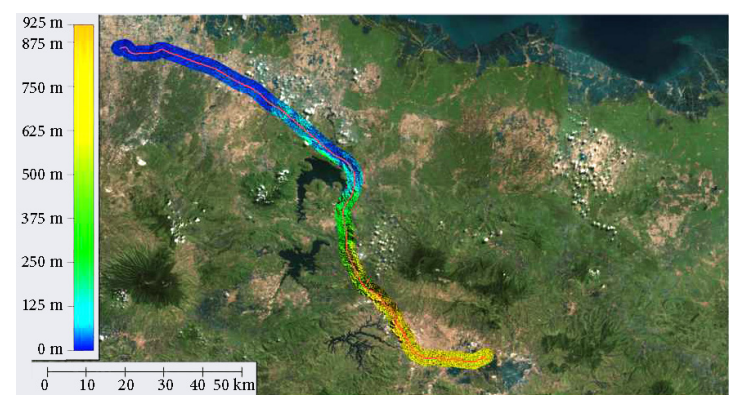

Figure 3. a - DSM X SAR of 2000 (up); b - DSM Sentinel of 2018 (bottom)
The methods used in the detection of vertical deformation are interferometry and DinSAR. Interferometry is used for making DSM. X SAR data is defined as master data and has a minimum vertical deformation $(\sim 0 \mathrm{~mm})$. Sentinel data is defined as slave data. X SAR was first made DSM (Figure 3a), while Sentinel was also made by DSM (Figure $3 b)$. This X SAR uses band X, while Sentinel uses band C. The difference in this band needs to be done in the reference field equation. This DSM X SAR and DSM Sentinel need to correct the height errors and correct the geoid undulations.

The height reference area of EGM 2008 was used to correct geoid undulations. Height error correction using a $5 \times 5$ matrix filter. After obtaining DSM 2000 and DSM 2018 which are height error-free and have the same height reference field, then DSM2DEM correction is done. This correction aims to turn DSM into DEM. DSM still has a surface covering vegetation and buildings. This correction will minimize vegetation and buildings so that it leaves soil elevation. This DEM is a DSM that has minimized vegetation and buildings. DEM is needed to detect vertical deformations that occur in an area. This DSM and DEM must meet the mapping tolerance that has been determined with certain requirements. At DSM and DEM only focused on vertical accuracy with $1.96 \sigma$ tolerance. If it has met the established tolerance (ASPRS, 2014), then DinSAR will do it. The DinSAR method used in this research is to reduce DEM 2018 with DEM 2000. The result of this reduction is vertical deformation. Figure 4 is the result of vertical deformation from DEM 2000 to DEM 2018.

After obtaining this DSM and vertical deformation, then the train route plan data is quickly overlaid to DSM and vertical deformation. This aims to find out where the location of the high speed train plan is. One method used is making a profile extending along the plan of a high speed train route. From the results of this longitudinal profile, it is known how the topographic conditions and vertical deformation along the route path that the high speed train will pass. Figure 5 is one example of a profile extending the plan of a high speed train route that passes through hills and rivers. Figure 5 is the initial location of the profile extending the direction of Jakarta to Bandung. This location is located at the coordinates (107.44229 east longitude; -6.79158 south latitude) until the coordinates (107.52566 east longitude; -6.8914798 south latitude).

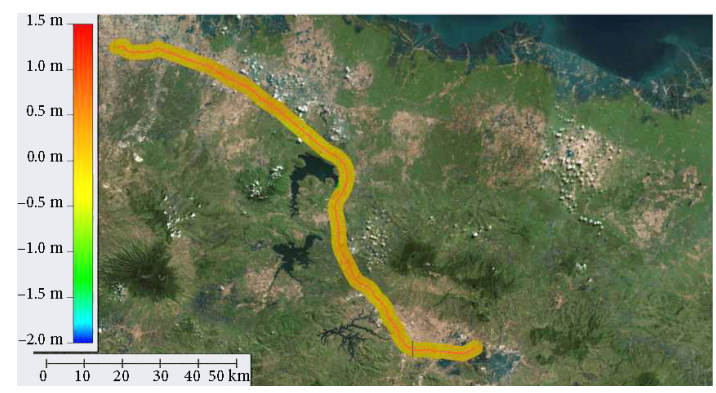

Figure 4. Vertical deformation from 2000-2018 


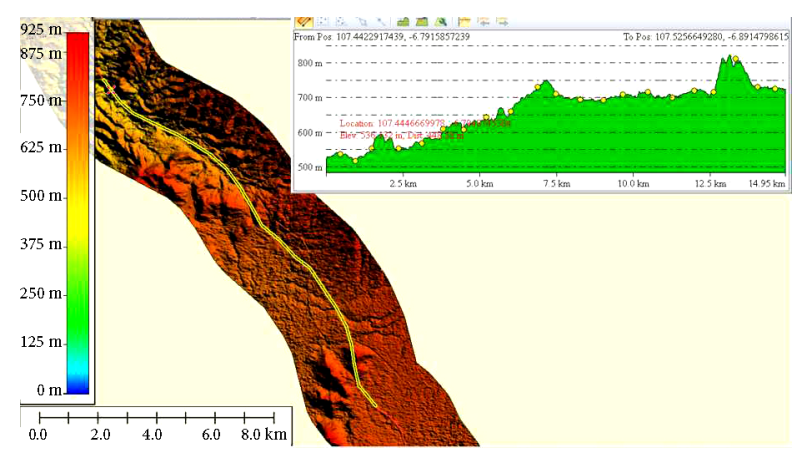

Figure 5. The profile extends on the planned high speed train route (the direction from Jakarta to Bandung) based on DEM 2018. The $x$ mark is the beginning of the longitudinal profile

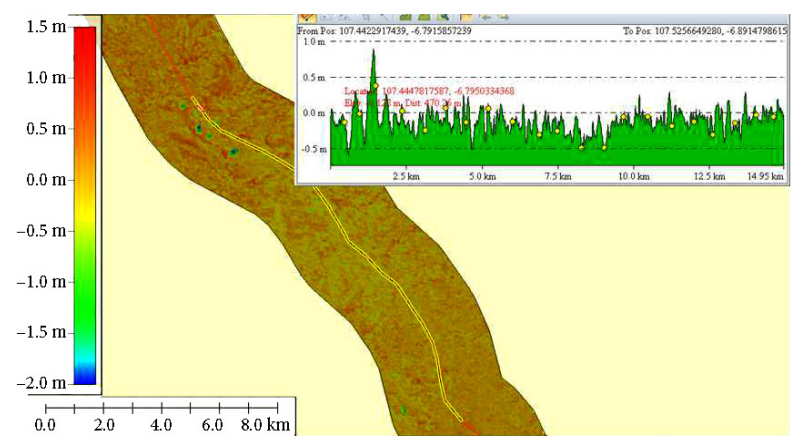

Figure 6. The longitudinal profile extends on the planned high speed railroad route (Jakarta direction towards Bandung) based on vertical deformation from 2000-2018. $\mathrm{x}$ is the beginning of a longitudinal profile

Figure 6 is the final location of the profile extending the direction of Jakarta to Bandung.

In addition, at the location of the sample at the beginning of the elongated profile (x mark) on the high speed track plan it can also be known vertical deformation. Vertical deformation in this area occurs at $\sim+0.2 \mathrm{~m}$ up to $-0.5 \mathrm{~m}$. This vertical deformation occurs in the 2000-2018 period, see Figure 6.

This longitudinal profile aims to find out topographic incisions and/or vertical deformations along the high speed train track. This elongated profile helps analyze $3 \mathrm{D} / 4 \mathrm{D}$ data accurately and in detail. This analysis can be done manually or digitally.

\subsection{Plans for the Jakarta-Bandung high speed train station}

The planned Jakarta-Bandung high speed train line will be made 4 Jakarta-Bandung train stations. Figure 7 is a plan for this high speed-train station.

Topographic conditions and vertical deformations that occur at 4 train stations can be detected by remote sensing data. Figure 8 is the topographic condition of station 1 and around. The way to do this is to overlay station 1 data point to 2018 DEM. While Figure 10 is vertical deformation that occurs at station 1 and around. The way to do this is to overlay station point 1 to vertical deformation from 2000 to 2018.

Station 1 is located in Jakarta. In this region the topography is located at a height of $7.5-23 \mathrm{~m}$. This varied value is due to the DSM being changed to DEM most likely located near the elevated toll road or between the multi-storey buildings. This has caused the correction of DSM to become a DEM to be less than optimal. However, precisely, it is not worrying about the vertical deformation detected because the high reference field DEM 2000 and DEM 2018 are the same and meet the requirements in the height difference test.

Station 1 has vertical deformation of $\sim+0.15 \mathrm{~m}$ to $-0.35 \mathrm{~m}$. The vertical deformation value occurred from 2000 to 2018 . Vertical deformation that occurred was still in a small scale stage and not a significant high deformation, see Figure 9.

Station 2 is located in Bekasi Regency. In this area the elevation of topography is located at $22-23 \mathrm{~m}$. This location is located adjacent to the river. Vertical deformations that occur in this region are $\sim 0.01 \mathrm{~m}$ to $-0.03 \mathrm{~m}$ from 2000 to 2018. This region has relatively small vertical deformations. The longitudinal profile of the high speed train route around Station 2 is also relatively flat within a $2 \mathrm{~km}$ radius, see Figure 10.

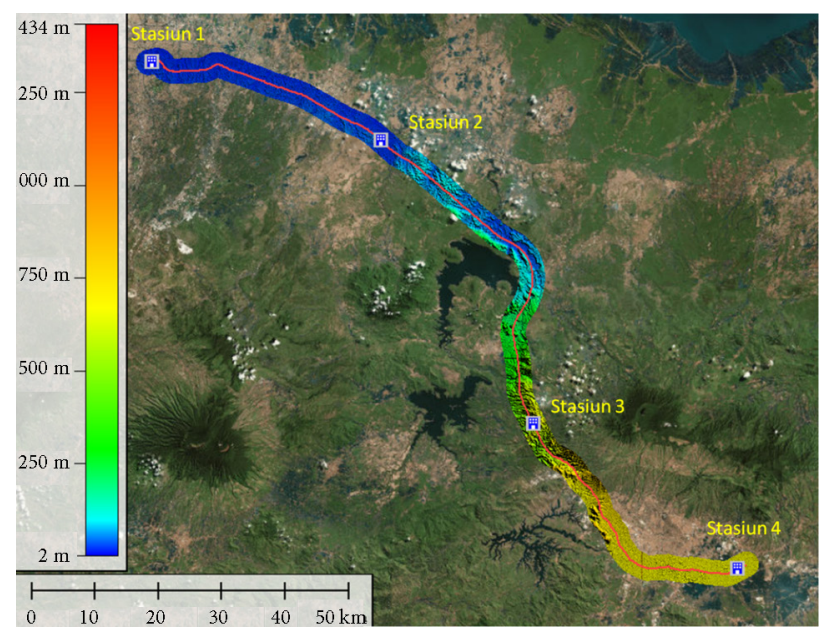

Figure 7. Plans for the Jakarta-Bandung high speed train station

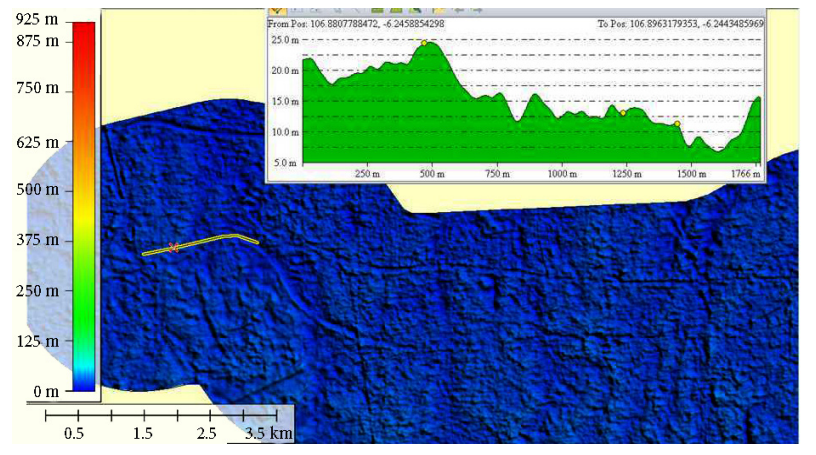

Figure 8. DEM 2018 in the planned station 1 Jakarta-Bandung high speed train 

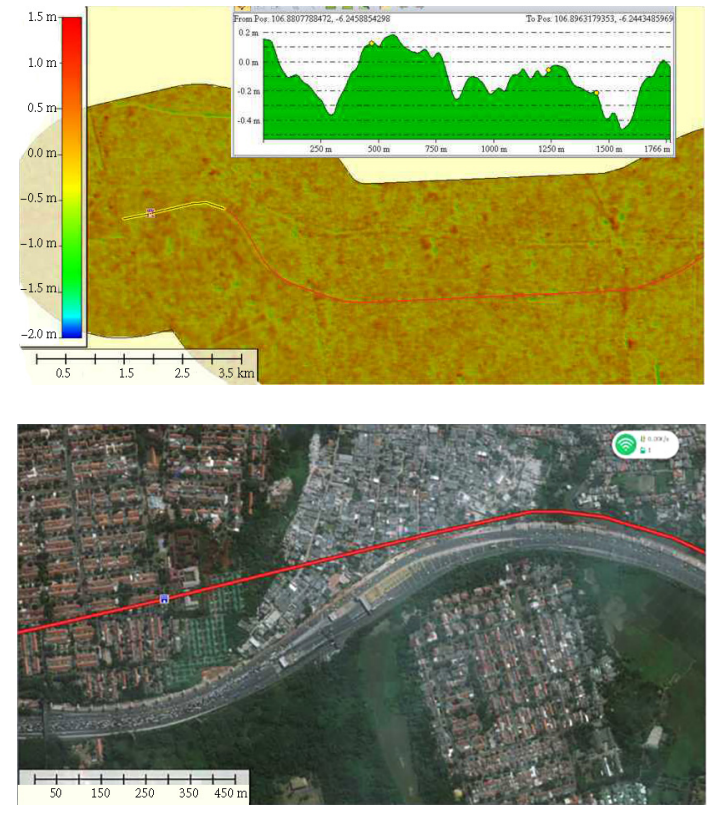

Figure 9. Vertical deformation at the planned station 1 JakartaBandung high speed train. Sign $x$ location of the planned Jakarta-Bandung high speed train station
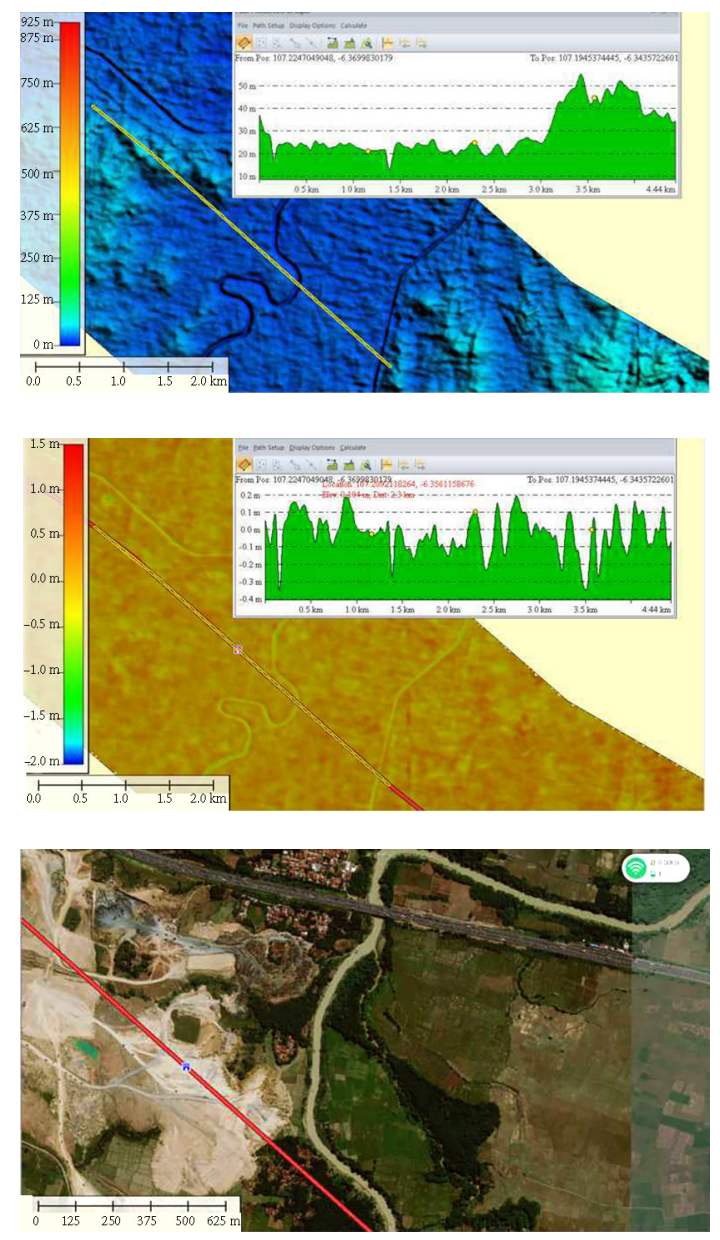

Figure 10. DEM 2018 (up) and vertical deformations from 2000-2018 (bottom) in station 2 plans and around. The $\mathrm{x}$ sign is the location of the planned station 2 Jakarta-Bandung high speed train
Station 3 is located in West Bandung Regency. In this region, the topography tends to be hilly. This hilly pattern can be seen from the elongated profile along the route that passes station 3. Station 3 is located at elevation of $562-563 \mathrm{~m}$. Vertical deformations that occur at station 3 and around are $\sim 0.05 \mathrm{~m}$ up to $0.5 \mathrm{~m}$ from 2000 to 2018 . Vertical deformation is relatively small at station 3 due to the influence of the geological conditions of the area and rarely landslides in the area around station 3. DEM and vertical deformation at station 3 can be seen in Figure 11.

Station 4 is located in Bandung Regency. Location checking in this paper is based on an overlay of the high speed train station plan point with an administrative limit (indicative) from the Geospatial Information Agency (BIG). This location has a relatively flat topography. This topography is located in a mixed area of rice fields with housing and several tall buildings. The elevation of station 4 is $661-662 \mathrm{~m}$. The area in station 4 has vertical deformation of $\sim 0.05 \mathrm{~m}$ to $-0.15 \mathrm{~m}$, see Figure 12.
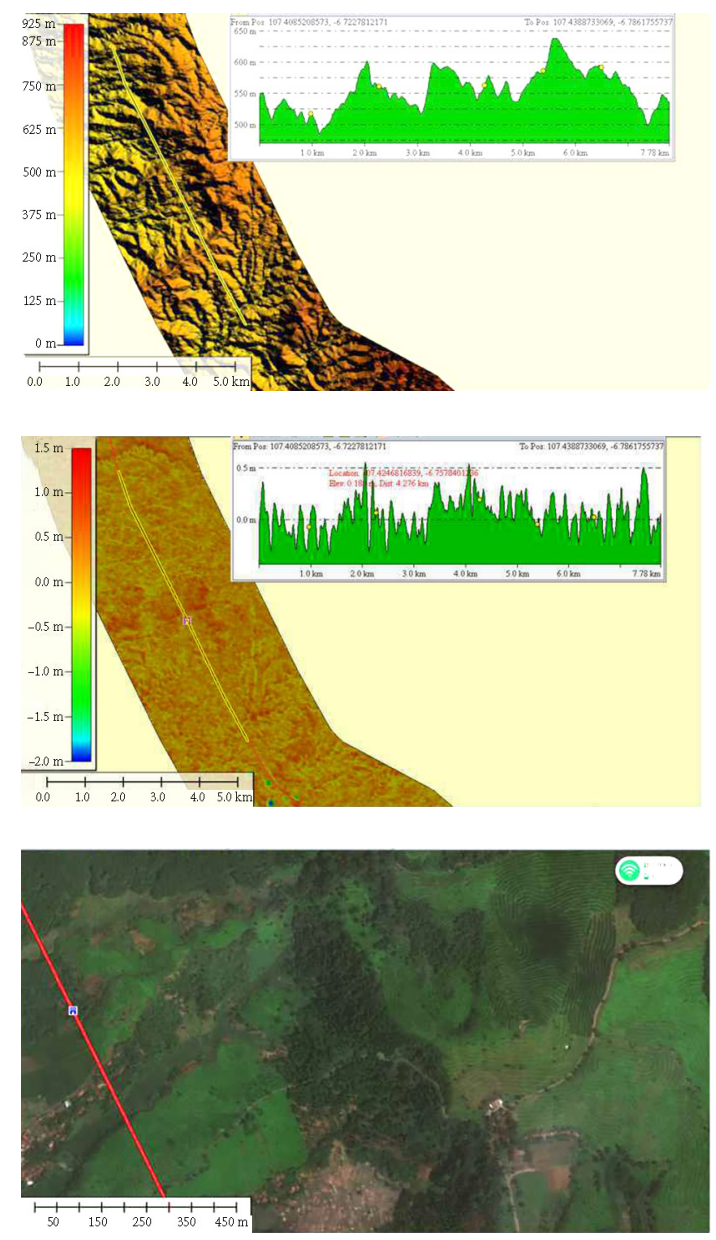

Figure 11. DEM 2018 (up) and vertical deformations from 2000-2018 (bottom) at station 3 and around plans. The $\mathrm{x}$ sign is the location of the planned station 3 of the Jakarta-Bandung high speed train 

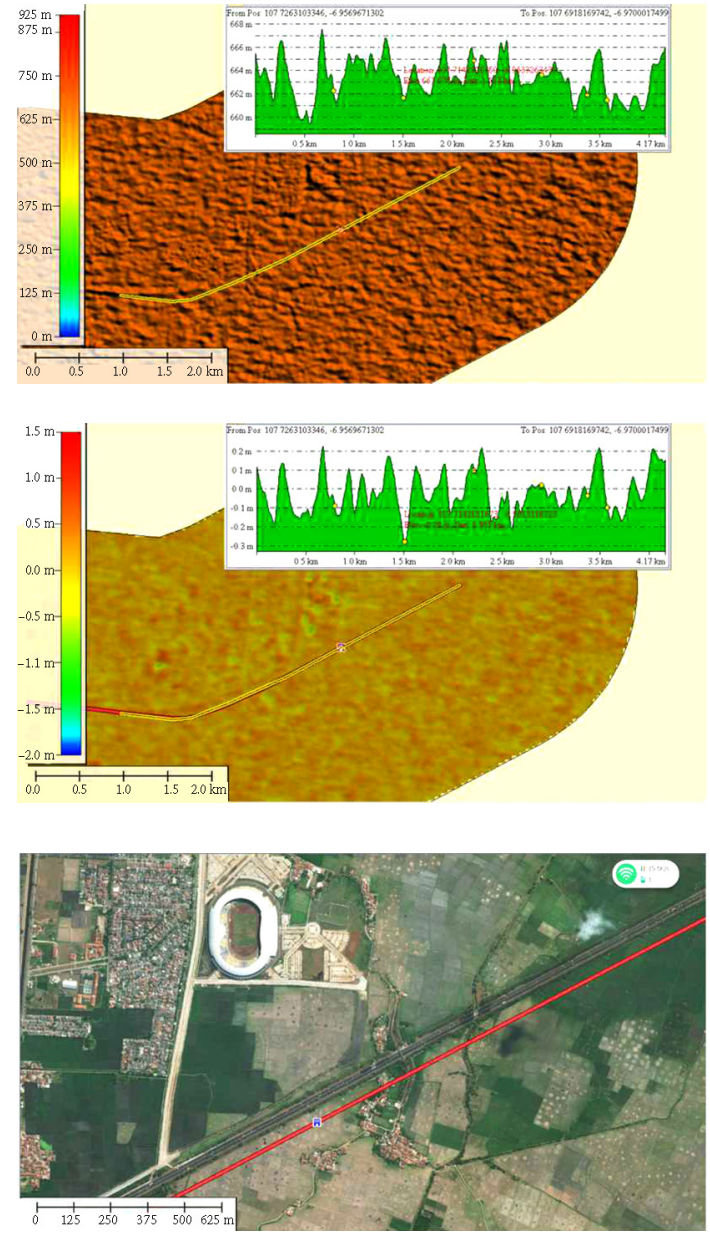

Figure 12. DEM 2018 (up) and vertical deformations from 2000-2018 (bottom) at station 3 and around plans. The $\mathrm{x}$ sign is the location of the planned station 3 of the Jakarta-Bandung hisg speed train

\section{Conclusions}

The Jakarta-Bandung high speed train line needs to be detected by the potential of vertical deformation. Vertical deformation made using 2000 X SAR data and Sentinels in 2018. The method used for making this vertical deformation is DinSAR. Vertical deformation values along this high speed train line are in the range of -0.35 to $+0.5 \mathrm{~m}$. The value also includes 4 high speed train stations. At station 1 area vertical deformation of $\sim+0.15 \mathrm{~m}$ to $-0.35 \mathrm{~m}$ is obtained. The area around station 2 undergoes vertical deformation of $\sim 0.01 \mathrm{~m}$ to $-0.03 \mathrm{~m}$. The area at station 3 undergoes vertical deformation of $\sim 0.05 \mathrm{~m}$ up to $0.5 \mathrm{~m}$. The area at station 4 which experiences vertical deformation is $\sim 0.05 \mathrm{~m}$ to $-0.15 \mathrm{~m}$. The largest vertical deformation occurs in the station area 3 . In general, vertical deformations that occur along the train line are rapidly deforming relatively small in 2000 to 2018 .

\section{Acknowledgements}

Thank you to Mr. Rizki for the Jakarta-Bandung high speed train track data. Thanks also go to Universitas
Gadjah Mada and LAPAN for supporting this activity. Thanks to DLR and ESA for the data used. Both authors are the main contributor in this paper.

\section{Disclosure statement}

The authors declare that there is no conflict of interest regarding the publication of this article. Authors confirmed that the data and the paper are free of plagiarism.

\section{References}

ASPRS. (2014). ASPRS accuracy standard for digital geospatial data. ASPRS, United States of America.

Bates, R. L. \& Jackson, J. A. (1987). Glossary of geology (3rd ed.). American Geological Institute, Alexandria.

Bemmelen, R. W. Van. (1949). The geology of Indonesia (Vol. 1 A). Government Printing Office, The Hauge.

Berardino, P., Fornaro, G., Lanari, R., \& Sansosti, E. (2002). A new algorithm for surface deformation monitoring based on small baseline differential SAR interferograms. IEEE Transactions on Geoscience and Remote Sensing, 40(11), 2375-2383. https://doi.org/10.1109/TGRS.2002.803792

Chang, L., Dollevoet, R., \& Hanssen, R. F. (2014). Railway infrastructure monitoring using satellite radar data. International Journal of Railway Technology, 3, 79-91. https://doi.org/10.4203/ijrt.3.2.5

Chang, L., Dollevoet, R. P. B. J., \& Hanssen, R. F. (2017). Nationwide railway monitoring using satellite SAR interferometry. IEEE Journal of Selected Topics in Applied Earth Observations and Remote Sensing, 10(2), 596-604. https://doi.org/10.1109/JSTARS.2016.2584783

Chang, L. \& Hanssen, R. F. (2016). A probabilistic approach for InSAR timeseries postprocessing. IEEE Transactions on Geoscience and Remote Sensing, 54(1), 421-430. https://doi.org/10.1109/TGRS.2015.2459037

Chrzanowski, A. (1986, October 31 - November 1). Geotechni$\mathrm{cal}$ and other non-geodetic method in deformation measurement. In Y. Bock (Ed.), Proceedings of the Deformation Measurement Workshop. Massachusetts Institute of Technology, Cambridge, MA.

Crosetto, M., Crippa, B., Biescas, E., Monserrat, O., Agudo, M., \& Fernández, P. (2005). Land deformation monitoring using SAR interferometry: state-of-the-art. Photogrammetrie, Fernerkundung und Geoinformation, 6, 497-510.

Crosetto, M., Monserrat, O., Cuevas, M., \& Crippa, B. (2011). Spaceborne differential SAR interferometry: data analysis tools for deformation measurement. Remote Sensing, 3, 305318. https://doi.org/10.3390/rs3020305

Cuenca, M. C., Hooper, A. J., \& Hanssen, R. F. (2013). Surface deformation induced by water influx in the abandoned coal mines in Limburg, the Netherlands observed by satellite radar interferometry. Journal of Applied Geophysics, 88, 1-11. https://doi.org/10.1016/j.jappgeo.2012.10.003

DLR. (2019). SRTM X. German Aespace Center (DLR). Retrieved 21 March 2019 from https://www.dlr.de/eoc/en/desktopdefault.aspx/tabid-5515/9214_read-17716/

European Space Agency. (2019). Sentinel satellites. European Space Agency. Retrieved 24 March 2019 from https://www. esa.int/Our_Activities/Observing_the_Earth/Copernicus/ Overview4

Esveld, C. (2001). Modern railway track. Zaltbommel, Netherlands: MRT Productions. 
Ferretti, A., Prati, C., \& Rocca, F. (2000). Nonlinear subsidence rate estimation using permanent scatterers in differential SAR interferometry. Transactions on Geoscience and Remote Sensing, 38(5), 2202-2212. https://doi.org/10.1109/36.868878

Ferretti, A., Prati, C., \& Rocca, F. (2001). Permanent scatterers in SAR interferometry. IEEE Transactions on Geoscience and Remote Sensing, 39(1), 8-20. https://doi.org/10.1109/36.898661

Ferretti, A., Fumagalli, A., Novali, F., Prati, C., Rocca, F., \& Rucci, A. (2011). A new algorithm for processing interferometric data-stacks: SqueeSAR. IEEE Transactions on Geoscience and Remote Sensing, 49(9), 3460-3470.

https://doi.org/10.1109/TGRS.2011.2124465

Fifamè Koudogbo, F., Urdiroz, A., Robles, J. G., Chapron, G., Lebon, G., Fluteaux, V., \& Priol, G. (2018). Radar interferometry as an innovative solution for monitoring the construction of the Grand Paris Express metro network - First results. TRE ALTAMIRA - tunnelcanada.ca. Retrieved from https://site. tre-altamira.com/wp-content/uploads/2018_InSAR_monitoring_Grand-Paris-Express-metro-construction_Koudogbo_et_al_WTC2018.pdf

Hanssen, R. F. (2001). Radar interferometry: Data interpretation and error analysis. Dordrecht, Netherlands: Springer. https://doi.org/10.1007/0-306-47633-9

Hyangsun, H., \& Hoonyol, L. (2011). Motion of Campbell glacier, east Antarctica, observed by satellite and ground-based interferometric synthetic aperture radar. In 3rd International Asia-Pacific Conference on Synthetic Aperture Radar (APSAR), 1(4), 26-30.

Julzarika, A. \& Susanto. (2009). Interferometric Synthetic Aperture Radar (Insar) applications for 3D modelling (DSM, DEM, dan DTM). Media sains dan teknologi dirgantara, 4(4), 154-159.

Jungner, A. (2009). Ground-based synthetic aperture radar data processing for $n t$ (Master thesis). Royal Institute of Technology (KTH), Division of Geodesy. Stockholm, Sweden.

Kuang, S. (1996). Geodetic network analysis and optimal design: Concepts and applications. Chelsea, Michigan: Ann Arbor, Inc.

Lillesand, T. M., \& Kiefer, R. W. (1994). Remote sensing and image interpretation (3rd ed.). New York, Chichester, Brisbane, Toronto, Singapore: John Wiley \& Sons.

Liu, G., Jia, H., Zhang, R., Zhang, H., Jia, H. \& Yu, B. (2011). Exploration of subsidence estimation by persistent scatterer InSAR on time series of high resolution TerraSAR-X images. IEEE Journal of Selected Topics in Applied Earth Observations and Remote Sensing, 4(1), 159-170. https://doi.org/10.1109/JSTARS.2010.2067446

Luo, Q., Perissin, D., Lin, H., Zhang, Y., \& Wang, W. (2014). Subsidence monitoring of Tianjin suburbs by TerraSAR-X persistent scatterers interferometry, IEEE Journal of Selected Top- ics in Applied Earth Observations and Remote Sensing, 7(5), 1642-1650. https://doi.org/10.1109/JSTARS.2013.2271501

Luzi, C., Del Ventisette, C., \& Casagli, N. (2010). Monitoring deformation of the sciara del fuoco (Stromboli) through ground-based radar interferometry. Acta Vulcanologica 22(1), 77-84.

Martodjojo. (1984). Evolusi Cekungan Bogor Jawa Barat. (Disertation). Institut Teknologi Bandung. Indonesia.

Monserrat, O. (2012). Deformation measurement and monitoring with ground-based SAR ( $\mathrm{PhD}$ thesis). Technical University of Catalonia.

Monserrat, O., Crosetto, M., \& Luzi, G. (2014). A review of ground-based SAR interferometry for deformation measurement. ISPRS Journal of Photogrammetry and Remote Sensing, 93, 40-48. https://doi.org/10.1016/j.isprsjprs.2014.04.001

Nico, G., Leva, D., Fortuny-Guasch, J., Antonello, G., \& Tarchi, D. (2005). Generation of digital terrain models with a groundbased SAR system. IEEE Transactions on Geoscience and Remote Sensing, 43(1), 45-49. https://doi.org/10.1109/TGRS.2004.838354

Pieraccini, M., Luzi, G., Mecatti, D., Fratini, M., Noferini, L., Carissimi, L., Franchioni, G., \& Atzeni, C. (2004). Remote sensing of building structural displacements using a microwave interferometer with imaging capability. NDT \& E International, 37(7), 545-550. https://doi.org/10.1016/j.ndteint.2004.02.004

Reale, D., Serafino, F., \& Pascazio, V. (2009). An accurate strategy for 3-D ground-based SAR imaging. IEEE Geoscience and Remote Sensing Letters 6(4), 681-685. https://doi.org/10.1109/LGRS.2009.2023537

Robles, J. G., Gomar, B. S., \& Arnaud, A. (2015). Non-linear motion detection using SAR images in urban tunnelling. In Proceedings of the ITA World Tunnel Congress, Dubrovnik, Croatia.

Rödelsperger, S., Becker, M., Gerstenecker, C., Läufer, G., Schilling, K., \& Steineck, D. (2010). Digital elevation model with the ground-based SAR IBIS-L as basis for volcanic deformation monitoring. Journal of Geodynamics, 49(3-4), 241-246. https://doi.org/10.1016/j.jog.2009.10.009

Ulaby, F. T., Moore, R. K., \& Fung, A. K. (1986). Microwave remote sensing: Active and passive: Vol. III. Scattering and emission theory, advanced systems and applications. Dedham, Massachusetts: Artech House Inc.

van Leijen, F. J. (2014). Persistent scatterer interferometry based on geodetic estimation theory. Delft, Netherlands: Geodetic Commission.

Wikipedia. (2018). High-speed rail in Indonesia. Retrieved 9 October 2018 from https://en.wikipedia.org/wiki/High-speed_ rail_in_Indonesia 